\title{
Paradoxical effects of glucocorticoids on regulation of plasminogen activator activity of rat hepatoma cells
}

(dexamethasone/hormonal regulation/protease)

\author{
P. A. Barouski-Miller and T. D. Gelehrter
}

Departments of Human Genetics and Internal Medicine, University of Michigan Medical School, Ann Arbor, Michigan 48109

Communicated by James V. Neel, January 4, 1982

\begin{abstract}
Incubation of rat hepatoma cells with cAMP derivatives stimulates cell-associated plasminogen activator activity 8- to 22 -fold and extracellular plasminogen activator activity 30 to $\mathbf{1 3 0 0}$-fold. This time- and concentration-dependent increase is enhanced by phosphodiesterase inhibitors. Dexamethasone, a synthetic glucocorticoid, decreases the plasminogen activator activity of these cells, probably through induction of an inhibitor. Paradoxically, dexamethasone, added simultaneously with cAMP derivatives causes a further 4-fold enhancement of the cAMPmediated stimulation of plasminogen activator activity. Dexamethasone also alters the time course of cAMP-mediated enhancement of plasminogen activator activity: increased protease activity is detected at $4 \mathrm{hr}$ in cells incubated with 8-bromoadenosine$3^{\prime}: 5^{\prime}$-cyclic monophosphoric acid and l-methyl-3-isobutylxanthine but not until $12 \mathrm{hr}$ in cells incubated with dexamethasone as well. Glucocorticoids thus exert two separate and opposite effects on plasminogen activator activity: induction of an inhibitor and amplification of cyclic nucleotide action. Although permissive and synergistic effects of dexamethasone on cyclic nucleotide action have been reported previously, glucocorticoid regulation of plasminogen activator activity is unique in that the amplification of cyclic nucleotide effects by dexamethasone opposes its regulatory action toward a specific enzyme.
\end{abstract}

Plasminogen activator (PA) converts the serum proenzyme plasminogen to plasmin, an active serine protease. Plasmin subsequently participates in fibrinolysis, complement and insulin production, cell migration, tissue remodeling, and tissue destruction. Increased PA activity has also been correlated with alterations in membrane structure and function associated with malignant transformation (for review, see ref. 1 and references cited therein).

Steroid and polypeptide hormones, cyclic nucleotides, retinoids, tumor promoters, and transforming genes alter PA activity in various cell types (for review, see ref. 2 and references cited therein). Glucocorticoids consistently decrease PA activity in responsive cell lines (3-10). In contrast, the magnitude and direction of cAMP regulation of PA activity varies greatly. Cholera toxin, cAMP derivatives, and phosphodiesterase inhibitors (and combinations thereof) increase PA activity in some cell lines (11-15) but decrease it in other lines $(3,4,16-19)$. Cells of identical species origin differ in their responses to cAMP modulation of PA activity; similarly, transformed or normal cells do not demonstrate a consistent pattern of response.

We examined the effect of 8 -bromoadenosine- $3^{\prime}: 5^{\prime}$-cyclic monophosphoric acid (8-Br-cAMP) and 1-methyl-3-isobutylxanthine (MIBX) on the PA activity of hepatoma tissue culture (HTC) cells, an established line of rat hepatoma cells (20).

The publication costs of this article were defrayed in part by page charge payment. This article must therefore be hereby marked "advertisement" in accordance with 18 U. S. C. \$1734 solely to indicate this fact.
We have shown that 8-Br-cAMP dramatically increases both cell-associated and extracellular PA activity in a time- and concentration-dependent fashion. Seifert and Gelehrter have previously reported that glucocorticoids decrease the PA activity of HTC cells, probably through the induction of an inhibitor (7). We therefore investigated the interaction of cAMP derivatives and dexamethasone, a synthetic glucocorticoid, in the regulation of PA activity. In this communication, we present evidence that dexamethasone paradoxically enhances cAMPmediated stimulation of PA activity presumably through some mechanism unrelated to its direct regulation of PA activity.

\section{MATERIALS AND METHODS}

Fibrinogen (98\% clottable) was purchased from Calbiochem-Behring. ${ }^{125}$ I-Labeled fibrinogen (specific activity, $\approx 150$ $\mu \mathrm{Ci} / \mathrm{mg} ; 1 \mathrm{Ci}=3.7 \times 10^{10}$ becquerels) was obtained from Amersham. Plasminogen was purified from human plasma by lysine-Sepharose chromatography (21). Dexamethasone was kindly provided by Walter Gall of Merck and Company. 8-BrcAMP and MIBX were purchased from Sigma. All other compounds were of reagent grade.

Cell Culture. HTC cells were grown in monolayer culture without antibiotics in Eagle's minimal essential medium for suspension culture (GIBCO)/50 mM N-[2-hydroxy-1,1-bis(hydroxymethyl)ethyl] glycine $/ 2 \mathrm{mM}$ glutamine $/ 0.02 \% \mathrm{CaCl}_{2} / \mathrm{NaHCO}_{3}$ $(0.5 \mathrm{~g} /$ liter $) / 8 \%$ calf serum (GIBCO) $/ 2 \%$ fetal bovine serum (GIBCO).

Glucocorticoid and cAMP Treatment. Cells were trypsinized from monolayer and plated at $2 \times 10^{6} / 35$-mm tissue culture dish in serum-supplemented medium $/ 0.02 \% \mathrm{CaCl}_{2}$. Confluent monolayers were washed twice with serum-free medium and incubated at $37^{\circ} \mathrm{C}$ in serum-free medium $/ 0.1 \%$ bovine serum albumin $/ 0.02 \% \mathrm{CaCl}_{2} /$ neomycin $(50 \mu \mathrm{g} / \mathrm{ml})$ containing 8-Br-cAMP, MIBX, and dexamethasone as described in table and figure legends. Control cultures contained $0.5 \%$ dimethyl sulfoxide (MIBX solvent) and $0.01 \%$ ethanol (dexamethasone solvent). Neither dimethyl sulfoxide nor ethanol affected PA activity or release.

PA Assay. PA activity was measured in a fibrin plate assay. ${ }^{125}$ I-Labeled fibrinogen plates were prepared as described by Strickland and Beers (22). Fibrinogen was converted to fibrin by incubation with $0.5 \mathrm{ml}$ of $5 \%$ fetal bovine serum/ $/ 0.1 \mathrm{M}$ Tris'base, $\mathrm{pH} 8.1$, at $37^{\circ} \mathrm{C}$ for $16 \mathrm{hr}$. Plates were then washed twice with phosphate-buffered saline and used within $24 \mathrm{hr}$ of activation. Total radioactivity per 16-mm-diameter well was the amount of radioactivity solubilized by $50 \mu \mathrm{g}$ of trypsin. Back-

Abbreviations: PA, plasminogen activator; 8-Br-cAMP, 8-bromoadenosine-3':5'-cyclic monophosphoric acid; MIBX, 1-methyl-3-isobutylxanthine. 
ground activity, the amount solubilized by an assay mixture of plasminogen and the appropriate volume of unconditioned medium (extracellular PA assays) or Triton X-100 (intracellular PA assays), was consistently $<3 \%$ of total radioactivity.

Cell extracts (in $0.02 \%$ Triton X-100) and extracellular medium were prepared as described $(7,23)$; cellular protein concentration was determined by the method of Lowry et al. (24). Cell extracts or medium, neither of which had plasminogen-independent fibrinolytic activity, were then assayed with $2 \mu \mathrm{g}$ of human plasminogen in a final volume of $1 \mathrm{ml}$ of $0.1 \mathrm{M}$ Tris base (pH 8.1) in fibrin-coated wells for $6 \mathrm{hr}$ at $37^{\circ} \mathrm{C}$. Solubilized radioactivity was corrected for background and then expressed as percentage of total radioactivity. Dexamethasone, 8-Br-cAMP, and MIBX had no effect on fibrinolytic activity when added directly to the assay.

The magnitude of cAMP-mediated enhancement of PA activity precluded measurement of control and cAMP samples within the same range of protein concentration or medium volume under identical assay conditions. Therefore, the PA activity of at least three (and generally four) different amounts of each sample was measured and the slope of the line (percentage of fibrin solubilized per microgram of cellular protein or microliter of extracellular medium) was determined by linear regression analysis. Slopes of duplicate cultures usually varied by $<15 \%$. The amount of solubilized fibrin per well was estimated from the amount of fibrinogen added initially and corrected for losses incurred during plate activation. Results were then expressed as microgram of fibrin solubilized per microgram of cellular protein or microliter of extracellular medium.

\section{RESULTS}

Enhancement of HTC Cell PA Activity by cAMP Derivatives. Incubation of wild-type HTC cells with 8-Br-cAMP and MIBX, a potent phosphodiesterase inhibitor, dramatically increases both cell-associated and extracellular PA activity (Table 1). In three separate experiments, 8-Br-cAMP with or without MIBX stimulated cell-associated PA activity 8- to 22-fold and extracellular PA activity 30 - to 1300 -fold (Table 1 and Fig. 1; unpublished data).

The enhancement of PA activity by 8-Br-cAMP is both concentration and time dependent. In the dose-response curve shown in Fig. 1, maximal stimulation (12-fold in cell extracts, 30 -fold in extracellular medium) is observed at $3 \mathrm{mM} 8-\mathrm{Br}$ cAMP, and stimulation is half-maximal at $0.2 \mathrm{mM} 8-\mathrm{Br}$-cAMP. A similar concentration dependence is noted for $N^{6}, \mathrm{O}^{2 \prime}$-dibutyryladenosine- $3^{\prime}: 5^{\prime}$-cyclic monophosphoric acid; the extent of

Table 1. Effect of 8-Br-cAMP, MIBX, and dexamethasone on PA activity of HTC cells

\begin{tabular}{|c|c|c|}
\hline \multirow[b]{2}{*}{ Addition } & \multicolumn{2}{|c|}{ PA activity } \\
\hline & Cell associated* & Extracellular ${ }^{\dagger}$ \\
\hline None (control) & $0.097 \pm 0.021$ & $0.003 \pm 0.0003$ \\
\hline 8-Br-cAMP & $0.88 \pm 0.03$ & $0.74 \pm 0.12$ \\
\hline 8-Br-cAMP/MIBX & $2.16 \pm 0.23$ & $3.92 \pm 0.18$ \\
\hline Dexamethasone & $0.024 \pm 0.006$ & ND \\
\hline $\begin{array}{c}\text { 8-Br-cAMP/MIBX/ } \\
\text { dexamethasone }\end{array}$ & $8.58+0.05$ & $18.16+6.32$ \\
\hline
\end{tabular}

HTC cells were incubated for $24 \mathrm{hr}$ in serum-free medium containing the indicated additions. 8-Br-cAMP was used at $3 \mathrm{mM}$, MIBX was used at $1 \mathrm{mM}$, and dexamethasone was used at $0.1 \mu \mathrm{M}$. Cell-associated and extracellular PA activities were measured on ${ }^{125}$ I-labeled fibrin plates. Results are expressed as slope \pm standard error of the slope (25). ND, not detectable.

* Expressed as $\mu \mathrm{g}$ of fibrin solubilized per $\mu \mathrm{g}$ of cellular protein.

+ Expressed as $\mu \mathrm{g}$ of fibrin solubilized per $\mu \mathrm{l}$ of extracellular medium.

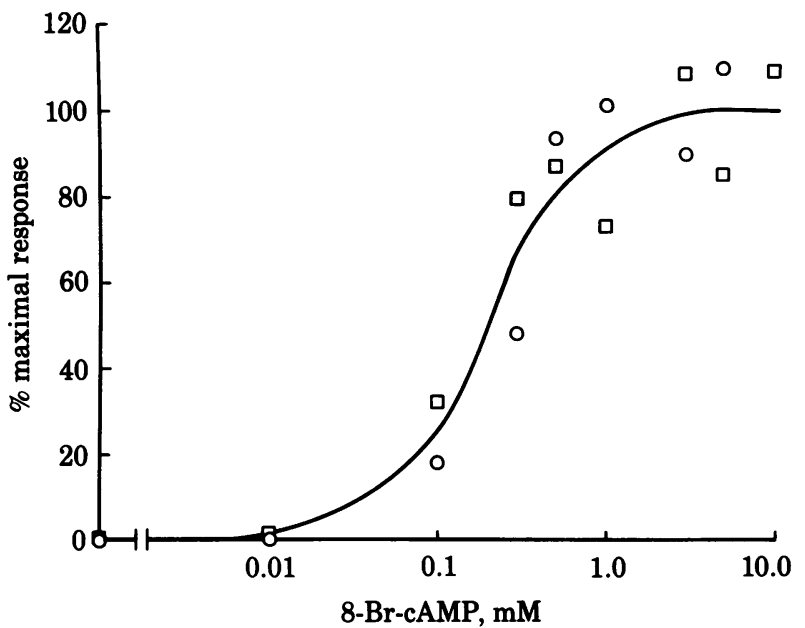

FIG. 1. Concentration-dependence of cAMP-mediated increases in PA activity. HTC cells were incubated for $18 \mathrm{hr}$ in serum-free medium containing various concentrations of 8-Br-cAMP. Cell-associated ( $\square$ ) or extracellular (O) PA activity is presented as a percentage of the maximal response. Maximal stimulation was 12-fold in cell extracts and 30 -fold in extracellular medium.

enhancement, however, is not as great (data not shown).

The time course of 8-Br-cAMP-mediated stimulation of PA activity is shown in Fig. 2. Increases in PA activity of cells in-
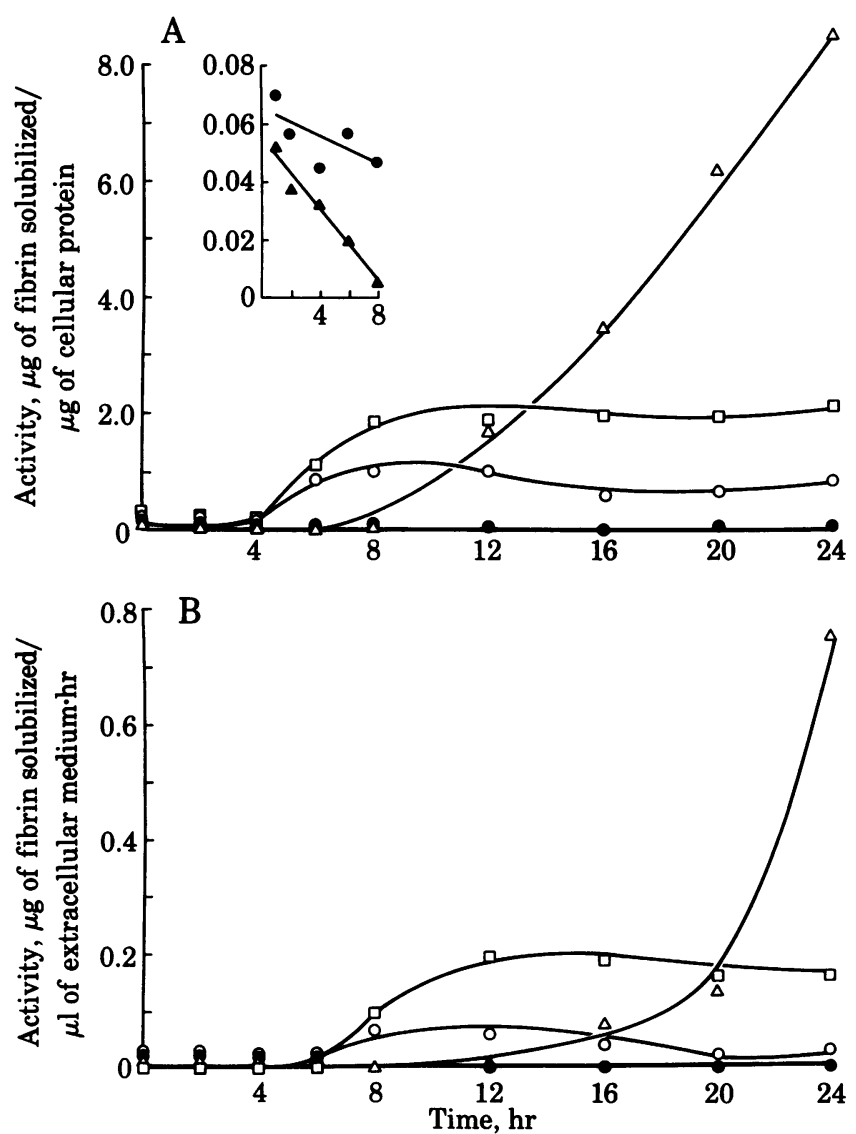

FIG. 2. Time course of 8-Br-cAMP action in the presence and absence of dexamethasone. HTC cells were incubated for $0-24 \mathrm{hr}$ in serum-free medium containing $0.1 \mu \mathrm{M}$ dexamethasone (A), $3 \mathrm{mM} 8-\mathrm{Br}$ cAMP (O), 3 mM 8-Br-cAMP/1 mM MIBX ( $($ ), or 3 mM 8-Br-cAMP/ $1 \mathrm{mM}$ MIBX/0.1 $\mu \mathrm{M}$ dexamethasone $(\triangle)$. $\bullet$ Control (no additions). $(A)$ Cell-associated PA activity. (B) Extracellular PA activity. (Inset) Expanded ordinate scale to demonstrate the effect of dexamethasone. 
cubated with 8-Br-cAMP are first detectable in these experiments at $4 \mathrm{hr}$ in cell extracts and at $6 \mathrm{hr}$ in extracellular medium and are maximal by 8 and $12 \mathrm{hr}$ respectively. MIBX increases the level of maximal stimulation but does not significantly alter the time course.

Dexamethasone Enhancement of cAMP-Mediated Increases in PA Activity. Dexamethasone decreases both cell-associated and extracellular PA activity of HTC cells, probably through the induction of an inhibitor (7). Paradoxically, dexamethasone, when added simultaneously with 8 -Br-cAMP and MIBX, enhances the cAMP-mediated increases of cell-associated PA activity 4-fold and of extracellular PA activity 5-fold (Table 1). The time course of cAMP action is profoundly altered by the addition of dexamethasone. Increases in cell-associated and extracellular PA activity of cells incubated with 8-Br-cAMP, MIBX, and dexamethasone are not detected until 12 and $16 \mathrm{hr}$, respectively (Fig. 2). PA activity remains elevated $48 \mathrm{hr}$ after treatment (unpublished experiments). Induction of an inhibitor by dexamethasone might explain the delay in detection of cAMP-mediated increases in PA activity; inhibitory activity has been detected in cells treated with 8-Br-cAMP, MIBX, and dexamethasone but not in cells treated with 8-Br-cAMP and MIBX (data not shown).

\section{DISCUSSION}

cAMP derivatives dramatically increase both cell-associated and extracellular PA activity of HTC cells. This time- and concentration-dependent effect is further enhanced by the addition of MIBX, a phosphodiesterase inhibitor.

The magnitude of cAMP-mediated stimulation of PA activity is particularly surprising. Unlike normal hepatocytes, HTC cells are unresponsive to regulation of growth rate and DNA synthesis or induction of phosphoenolpyruvate carboxykinase by dibutyryl cAMP (26); similar treatment only modestly induces tyrosine aminotransferase $(27,28)$.

Glucocorticoids, in contrast, induce several striking phenotypic alterations in HTC cells: induction of tyrosine aminotransferase, inhibition of amino acid transport, an increase in adhesiveness, and an increase in the number of cell surface microvilli (29). In addition, dexamethasone rapidly decreases both cell-associated and extracellular PA activity, probably through induction of an inhibitor (7). Paradoxically, simultaneous addition of dexamethasone, 8-Br-cAMP, and MIBX causes even greater stimulation of PA activity than that observed with only the latter two agents. These results suggest at least two separate and opposite effects of glucocorticoids on PA activity: induction of an inhibitor and amplification of cyclic nucleotide action. The delay in the time course of cAMP-mediated stimulation of PA in the presence of dexamethasone, as well as the presence of inhibitory activity in cells treated with the combination of 8-Br-cAMP, MIBX, and dexamethasone, supports the hypothesis of inhibitor induction by dexamethasone.

cAMP derivatives and glucocorticoids may alter PA activity by regulating the synthesis or activity of different forms of PA. Using an agar-fibrin overlay technique (30), we have observed that HTC cells exhibit a major band of PA activity at $M_{\mathrm{r}} 66,000$ and one minor band of activity at $M_{\mathrm{r}} 110,000$. Incubation of cells with 8-Br-cAMP in the presence or absence of dexamethasone causes a dramatic increase in the activity of the major $M_{r} 66,000$ species (unpublished data), suggesting that glucocorticoids and cAMP derivatives alter the expression of the same PA gene(s) or gene product. Alternatively, treatment with cAMP derivatives might decrease the amount or activity of an endogenous inhibitor of PA, thereby increasing the net PA activity. Current data do not differentiate between these hypotheses: stimulation of PA activity by cAMP derivatives could result from increased PA activity, decreased inhibitor activity, or both.

Granner (31) has reported a permissive action of dexamethasone on the induction of tyrosine aminotransferase by dibutyryl cAMP in HTC cells. Similar permissive and synergistic actions of glucocorticoids with other hormones and effectors have been observed in a wide array of biological processes (31); however, the mechanism of steroid enhancement has not yet been identified $(31,32)$. Glucocorticoid enhancement of cAMP-mediated stimulation of PA activity is unique in that the glucocorticoid opposes its own regulatory action on a specific enzyme.

The availability of several classes of glucocorticoid-resistant variants makes HTC cells a favorable model system for further investigation of the interactions of glucocorticoids and cyclic nucleotides in the regulation of PA activity. Seifert and Gelehrter have previously isolated HTC cell variants that are fully resistant to glucocorticoid regulation of $\mathrm{PA}$ activity yet retain other glucocorticoid-mediated responses (33). In preliminary experiments, glucocorticoids amplified cAMP-mediated stimulation of PA activity in these hepatoma cell variants (unpublished data). Another class of variants appears to lack glucocorticoid receptors (34); a third type is defective in steroidal induction of transaminase and inhibition of phosphodiesterase but retains wild-type regulation of PA activity (35). Biochemical analysis of these variant cell lines should help elucidate the mechanism(s) of glucocorticoid enhancement of cAMP action.

This research was supported by Grant CA 22729 from the National Cancer Institute. P.A.B. was supported by Predoctoral Training Grant GM 97544 from the National Institutes of Health and T.D.G. was the recipient of a Faculty Research Award from the American Cancer Society.

1. Reich, E. (1978) in Biological Markers of Neoplasia: Basic and Applied Aspects, ed. Ruddon, R. (Elsevier, North-Holland, New York), pp. 491-500.

2. Kucherlupati, T., Tepper, R., Granelli-Piperno, A. \& Reich, E. (1978) Cell 15, 1331-1340.

3. Vassalli, J. D., Hamilton, J. \& Reich, E. (1976) Cell 8, 271-281.

4. Granelli-Piperno, A., Vassalli, J. D. \& Reich, E. (1977) J. Exp. Med. 146, 1693-1706.

5. Laishes, B. A., Roberts, E. \& Burrowes, C. (1976) Biochem. Biophys. Res. Commun. 72, 462-471.

6. Wigler, M., Ford, J. \& Weinstein, I. B. (1975) in Proteases and Biological Control, eds. Reich, E., Rifkin, D. \& Shaw; E. (Cold Spring Harbor Laboratory, Cold Spring Harbor, NY), pp. 849-856.

7. Seifert, S. C. \& Gelehrter, T. D. (1978) Proc. Natl. Acad. Sci. USA 75, 6130-6133.

8. Werb, Z., Mainardi, C. L., Vater, C. A. \& Harris, E. D. (1977) N. Engl. J. Med. 296, 1017-1023.

9. Werb, Z. (1978) J. Exp. Med. 147, 1695-1712.

10. Roblin, R. \& Young, P. L. (1980) Cancer Res. 40, 2706-2713.

11. Miskin, R., Easton, T. G. \& Reich, E. (1978) Cell 15, 1301-1312.

12. Beers, W. H., Strickland, S. \& Reich, E. (1975) Cell 6, 387-394.

13. Lacroix, M., Smith, F. E. \& Fritz, I. B. (1977) Mol. Cell. Endocrinol. 9, 227-236.

14. Linney, E. \& Levinson, B. B. (1977) Cell 10, 297-304.

15. Laug, W. E., Jones, P. A., Nye, C. A. \& Benedict, W. F. (1976) Biochem. Biophys. Res. Commun. 68, 114-119.

16. Rosen, N., Schneck, J., Bloom, B. R. \& Rosen, O. M. (1978) J. Cyclic Nucleotide Res. 5, 345-358.

17. Mott, D. M., Fabisch, P. H. \& Sorof, S. (1976) Biochem. Biophys. Res. Commun. 70, 1150-1156.

18. Wilson, E. L. \& Reich, E. (1979) Cancer Res. 39, 1579-1586.

19. Shepro, D., Schleff, R. \& Hechtman, H. B. (1980) Life Sci. 26, 415-422.

20. Thompson, E. B., Tomkins, G. M. \& Curran, J. F. (1966) Proc. Nath Acad. Sci. USA 56, 296-303.

21. Deutsch, D. G. \& Mertz, E. T. (1970) Science 170, 1095-1096. 
22. Strickland, S. \& Beers, W. H. (1976) J. Biol. Chem. 251, 5694-5702.

23. Barouski, P. A. \& Gelehrter, T. D. (1980) Biochem. Biophys. Res. Commun. 96, 1540-1546.

24. Lowry, O. H., 'Rosebrough, N. J., Farr, A. L. \& Randall, R. J. (1951) J. Biol. Chem. 193, 265-275.

25. Neter, J. \& Wasserman, W. (1974) Applied Linear Statistical Models (Irwin-Dorsey, Georgetown, ON), p. 56.

26. van Rijn, H., Bevers, M. M., van Wijk, R. \& Wicks, W. D (1974) J. Cell Biol. 60, 181-191.

27. Stellwagen, R. H. (1972) Biochem. Biophys. Res. Commun. 47, $1144-1150$.

28. Hargrove, J. L., Volentine, G. \& Granner, D. K. (1981) J. Steroid Biochem. 14, 101-108.
29. Gelehrter, T. D. (1979) in Glucocorticoid Hormone Action, ed. Baxter, J. D. \& Rousseau, G. G. (Springer, Berlin), pp. 561-574.

30. Granelli-Piperno, A. \& Reich, E. (1978) J. Exp. Med. 148, 223-234.

31. Granner, D. K. (1979) in Glucocorticoid Hormone Action, eds. Baxter, J. D. \& Rousseau, G. G. (Springer, Berlin), pp. 593-611.

32. Rousseau, G. G. (1977) Eur. J. Biochem . 76, 309-316.

33. Seifert, S. C. \& Gelehrter, T. D. (1979) J. Cell Physiol. 99, 333-342.

34. Grove, J. R., Dieckmann, B. S., Schroer, T. A. \& Ringold, G. M. (1980) Cell 21, 47-56.

35. Thompson, E. B., Granner, D. G., Gelehrter, T. D., Erickson, J. \& Hager, G. L. (1979) Mol. Cell. Endocrinol. 15, 135-150. 